\title{
Assessment of structure and sensory characteristics of reduced fat yoghurt manufactured with carob bean gum polysaccharides
}

\author{
Pinar AYDINOL SONMEZ1, Tulay OZCAN²* (D)
}

\begin{abstract}
In recent years, since excess adiposity is thought to be responsible for the development of chronic diseases, many ingredients have been developed for the specific purpose of fat replacement in functional dairy foods. Carob bean gum (CBG) is widely used in food systems to modify quality attributes and shelf-life as thickening and gelling agents. Objective of this study was to develop reduced fat (12\%) and low fat (6\%) yoghurt using $\mathrm{CBG}$ as a carbohydrate based fat replacer. The results revealed that the addition of CBG increased the textural and sensory attributes of reduced fat yoghurts. In this present study, the textural properties such as firmness, and stickiness of yoghurt samples were significantly higher in the low fat yoghurt (6\%, T5) with $\mathrm{CBG}$, and yellowness index was increased in low fat (6\%, T3 and T5) yoghurts. The addition of CBG to reduced fat and low fat yoghurts (T4, T5) improved the sensory properties and acceptance index.
\end{abstract}

Keywords: yoghurt; carob bean gum polysaccharides; fat replacer.

Practical Application: Production of reduced fat milk products with carob bean gum polysaccharides.

\section{Introduction}

Human metabolism contains certain amounts of fat with its energy content, essential fatty acid source, carrier for fatsoluble vitamins and physiological effects throughout life. Milk fats contribute to nutritional and functional properties of dairy products such as palatability, smoothness, melting, oiling off, shredability, appearance, plasticity and feeling of satiety (Delaš, 2011; DeHond et al., 2018).

Fat-reduced or low-fat foods; refers to "foods that have a lower fat content than the reference fat ratio" (Calorie Control Council, 2002). Nowadays, health problems related to obesity, diabetes mellitus, metabolic and coronary syndrome, hypertension, cancer and neurological disorders syndrome have led to greater consumer awareness for healthier fat-reduced foods (Brennan \& Tudorica, 2008). As a result, the demand for low-calorie foods has increased and many researchers have been done especially in dairy products to reduce the amount of fat in foods and to develop new products with the use of oil-like substances (Lim et al., 2010).

Given the rapidly growing world population, dairy product that has an important place in human nutrition. Milk fat in fermented dairy products; besides being a source of energy, also plays a role in techno-functional characteristics such as textural, flavour and aroma profile (Brennan \& Tudorica, 2008; Ceylan \& Ozcan, 2020). However, reduction of fat in fermented dairy products caused the bland, harder, and more rubbery/chewy texture, colour and melting defects compared to its full-fat system (Aryana \& Haque, 2001; Dai et al., 2018). In order to prevent defects caused by fat reduction in cheese; modification of the production process, selection of suitable starter cultures, auxiliaries and enzymes, use of fat substitutes are methods applied (Brighenti et al., 2008; Janhoj et al., 2009; Lashkari et al., 2014; Aydinol \& Ozcan, 2018).

Fat replacers are used as fat substitutes, fat mimetics, and their combinations. Carbohydrate based fat mimetics improve the quality of the water phase, creating a creamy, smooth texture and greasy feel. Dietary fibers can be given as an example of carbohydrate-based fat imitations. In recent years, it has become widespread to produce foods enriched with dietary fibers by the use of cereals, vegetables, fruits and various herbal additives in dairy products for the enhancement of therapeutic quality and texture (Sandrou \& Arvanitoyannis, 2000; Metzger \& Kapoor, 2007).

Carob bean gum (CBG), known as locust bean gum (LBG) is a neutral polysaccharide belonging to the group of galactomannans, being extracted from the seeds endosperm of the carob (locust) tree (Ceratonia siliqua) (Dionísio \& Grenha, 2012). Carob gum is produced from carob tree plant, which belongs to the Caesalpinioideae subfamily of the Leguminosae family (Batal et al., 2013). Carob tree in Mediterranean countries, mainly Spain, Italy, Cyprus, Morocco, Greece, Algeria, Turkey, Israel and North Africa is also common. It is also grown in different parts of South America and Asia (Barak \& Mudgil, 2014). Carob seeds consist of about $80 \%$ galactomannan, the rest are proteins, and other components (Bouzouita et al., 2007; Bengoechea et al., 2008) and carob polysaccharides are widely used in different therapeutic foods. The ground of endosperm is used to produce CBG, as a food additive that is coded E-410. It is 
used as a thickener, stabilizer and fat replacer in dairy products (Pollard et al., 2007).

Carob seeds contain high molecular weight (approximately $50-3,000 \mathrm{kDa}$ ) hydrocolloidal polysaccharides about $300-400 \mathrm{~g} \mathrm{~kg}^{-1}$ of pure carob galactomannan (two units i.e galactose and mannose) which consists of a linear chain of $(1 \rightarrow 4)$-linked -d-mannopyranosyl units with ( $1 \rightarrow 6$ )-linked -d-galactopyranosyl residues as side chains (Dakia et al., 2008; Moreira \& Ferreira, 2008; Zhu et al., 2019).

Yoghurt is a nutraceutical milk product in the world. It is sometimes produced by concentrating milk to approximately $23-28 \%$ total solids ( $w / v$ ) by the method of ultrafiltration, reverse osmosis, or direct reconstitution in the Eastern Mediterranean countries. This study aims to develop reduced fat $(12 \%)$ and low fat (6\%) yoghurt using CBG polysaccharides and assessment of technological characteristics of reduced-fat yoghurt.

\section{Materials and methods}

\subsection{Yoghurt manufacturing}

Milk standardized to $18 \%$ (full-fat control yoghurt, Treatment 1, T1), 12\% (reduced fat control yoghurt, T2) and 6\% (low fat control yoghurt, T3) fat ratio with homogenized and pasteurized cream. $0.8 \% \mathrm{w} / \mathrm{w}$ CBG (Alfasol, Istanbul/Turkey) was added into reduced fat $(12 \%, \mathrm{~T} 4)$ and low fat $(6 \%, \mathrm{~T} 5)$ milk and pasteurized $\left(85^{\circ} \mathrm{C}\right)$. Cooled milk was inoculated with $3 \%$ yoghurt culture consisting of Streptococcus thermophilus and Lactobacillus delbrueckii subsp. bulgaricus (purchased from Clarici Sacco, Italy) and incubated at $42{ }^{\circ} \mathrm{C}$.

\subsection{Methods}

Textural characteristics were determined on TA-XT Plus Texture Analyzer (Stable Micro Systems) using firmness and stickiness parameters (Aydinol \& Ozcan, 2018). Lactic acid profile was determined by high-performance liquid chromatography (HPLC) using the method modified by Canbulat \& Ozcan (2015). The colour properties $L^{*}$ (whiteness), and $b^{*}$ (intensity of yellow to blue values) were determined by the method of Pathare et al. (2013) using a Hunter Colour Instrument (MSEZ4500 L; Virginia 20190, USA). Yellowness index (YI) indicates the degree of yellowness associated with processing conditions and general product degradation by light, heat and chemical exposure was calculated as follows (Equation 1):

$\mathrm{YI}=142.86 \mathrm{~b}^{*} \mathrm{~L}^{-1}$

Sensory properties (appearance, thickness, odour, colour, flavour, after taste, overall liking) of yoghurt samples were analyzed by trained panelists using 5 point hedonic scale (1=strongly disliked; $2=$ =moderately/slightly disliked; $3=$ indifferent; $4=$ moderately/slightly liked; and $5=$ strongly liked). The acceptability index (AI) of consumer preference was calculated according to the equation $\mathrm{AI}(\%)=\mathrm{Y}^{\star} 100 / \mathrm{Z}(\mathrm{Y}=$ the average score obtained for the product, and $\mathrm{Z}=$ maximum score given to the product) (Silva et al., 2010; Kaaki et al., 2012).
The data were analysed by an analysis of variance (ANOVA) using Statistica 9.2 software (StatSoft, Inc., Tulsa, OK, USA) and differences were compared by the Tukey test at $5 \%$ and $1 \%$ of significance.

\section{Results and discussion}

Texture represents rheological, structural and sensorial properties, which affected with casein matrix density and fat globules embedded within the protein matrix. Increasing casein bond strength and density results in enhanced firmness of the matrix of the food. Besides, fat has the significant role in milk gel structure that improves the textural properties of fermented products such as firmness, stickiness, cohesiveness, spreadability, shininess, compactness, and creaminess (Rogers et al., 2010; Kaaki et al., 2012; Ozcan, 2013).

Textural properties of the samples were shown in Figure 1. Significant differences between reduced fat $(12 \%)$ and low fat $(6 \%)$ yoghurt produced with CBG $(P<0.01)$ were observed. In this study firmness and stickiness properties of low fat (T5) yoghurts with CBG samples were significantly higher due to the emulsification property of $\mathrm{CBG}$ and new formation of milk gel. In a general manner, neutral polysaccharide $\mathrm{CBG}$ is play roles in food processing as thickening, gelling, emulsifying, hydrating and suspending agents and as fiber-based fat mimetic (Rinaudo, 2008; Dionísio \& Grenha, 2012). Lobato-Calleros et al. (2002) explained using fat-replacers give rise to new structures and matrix than whole milk gels due to the interactions between the casein chains and the fat-replacers.

As a carbohydrate-based fat substitute, gums are widely used to stabilize the structure, improve gel formation and nutraceutical properties in the food matrix changing by reducing the fat content (Simeone et al., 2004; Totosaus \& Guemes-Vera, 2008; Yilmaz-Ersan et al., 2018). Romeih et al. (2002) explained that hardness of dairy products produced with hydrocolloid, as fat mimetic was very similar to the full-fat products.

Stickiness values of samples were significantly affected by fat reduction in reduced fat (T4) and low fat (T5) yoghurt with CBG. Gunasekaran \& Ak (2003) reported that the firmness of fermented products reflects the solid to fat ratio, macrostructure, heterogeneities of granules in fermented milk matrix. CBG increased firmness while enhancing of stickiness and preventing serum separation such as explained by Duboc \& Mollet (2001).

The ratio of organic acids (especially lactic acid and acetic acid) metabolites produced during normal metabolism of LAB depending on fermentation type and medium conditions. The rate of lactic acid production increases when the conditions of the medium are favourable for the growth of the bacterium (Alwazeer et al., 2020). Figure 2 shows the lactic acid profile of yoghurt using CBG $(p<0.01)$. During yoghurt fermentation, lactic acid is produced with lactose consumption by the yoghurt bacteria, Lactobacillus delbrueckii subsp. bulgaricus and Streptococcus thermophilus (Leroy \& De Vuyst, 2004; Ribeiro et al., 2019). As a result, the acidity was increased while $\mathrm{pH}$ is decreased in samples due to the interactions with hydrocolloid and milk proteins. $\mathrm{CBG}$ is non-ionic, it is not affected by $\mathrm{pH}$ or ionic 

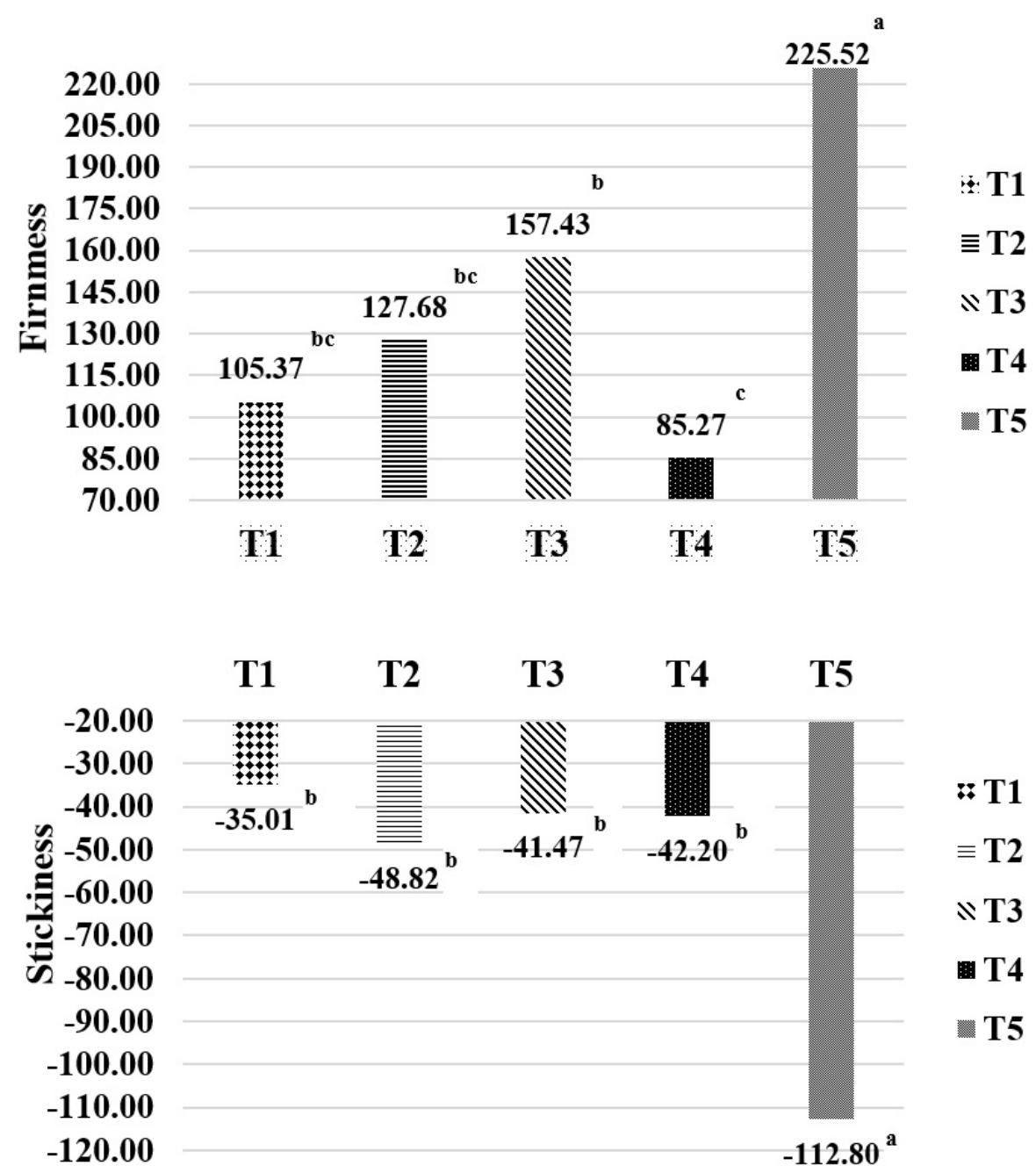

(b)

Figure 1. Textural properties of yoghurt samples using CBG, (a) Firmness; (b) Stickiness. T1: Full fat yoghurt (18\%), T2: Reduced fat yoghurt (12\%), T3: Low fat yoghurt (6\%), T4: Reduced fat yoghurt with CBG (12\%), T5: Low fat yoghurt with CBG (6\%).

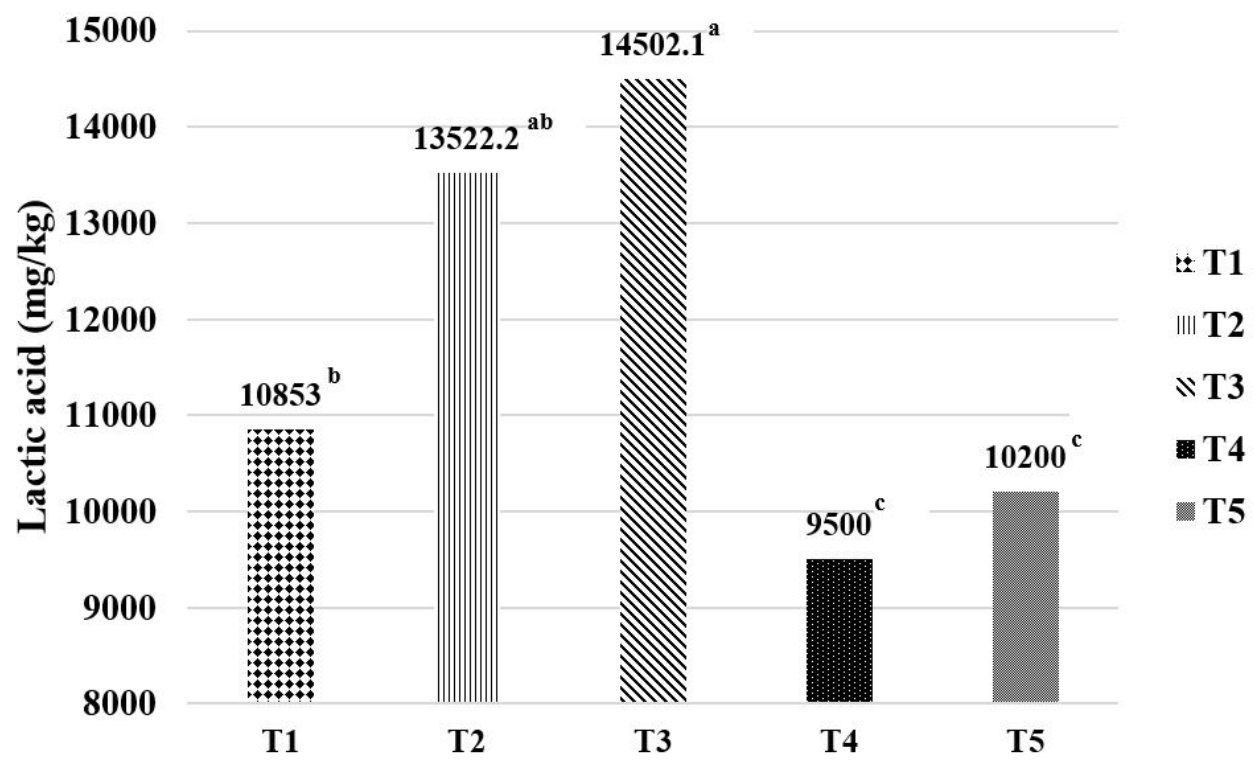

Figure 2. Lactic acid profile of yoghurt samples using CBG. T1: Full fat yoghurt (18\%), T2: Reduced fat yoghurt (12\%), T3: Low fat yoghurt (6\%), T4: Reduced fat yoghurt with CBG (12\%), T5: Low fat yoghurt with CBG (6\%). 
strength. So lactic acid amount was higher in T3 sample than yoghurt with $\mathrm{CBG}$.

Yellowness Index (YI) indicates the degree of yellowness that changes in colour of yoghurt samples from clear or white to yellow and is associated with $b^{*}$ (displays positive values for yellowish colours with CIELAB coordinates) values (Barros et al., 2020). Yellowness index (YI) is describes the. CBG occurs as a white to yellow-white powder. YI values of yoghurt samples were given Figure 3. In this study YI was increased in low fat (6\%) yoghurts (T3 and T5) $(p<0.01)$. Results were suggested that YI was influenced based on the amount of yellowness-blueness, $b^{*}$ when the absolute value of $b^{\star}$ was increasing, YI of the samples was increased (Jung \& Sato, 2013).

The sensory properties of yoghurt were shown in Figure 4. In the study sensory attributes were significantly affected by fat reduction using CBG $(p<0.01)$. Fat and protein content of fermented products and degradation effect the changes in colour (Sattar et al., 2015). Folkenberg \& Martens (2003) stated that the fat content of yoghurts affects important sensory parameters such as odour, taste, and texture, so the changes formed as a result of the activity of the fermentation culture and their additional additives can replace the milk fat.

Acetaldehyde, acetoin and diacetyl are accepted as the main sensory components contributing to yoghurt flavour and consumer choice (Arslaner, 2020). This study established a significant effect of colour and flavour of all yoghurt samples affected by fat reduction. All sensory properties of $6 \%$ fat yoghurts (T3) (appearance, thickness, odour, colour, aroma, after taste and overall liking) had the lowest values in spite of the fact that $18 \%$ and $12 \%$ fat yoghurts (T1, and $\mathrm{T} 2$ ) had the highest values $(p<0.01)$.

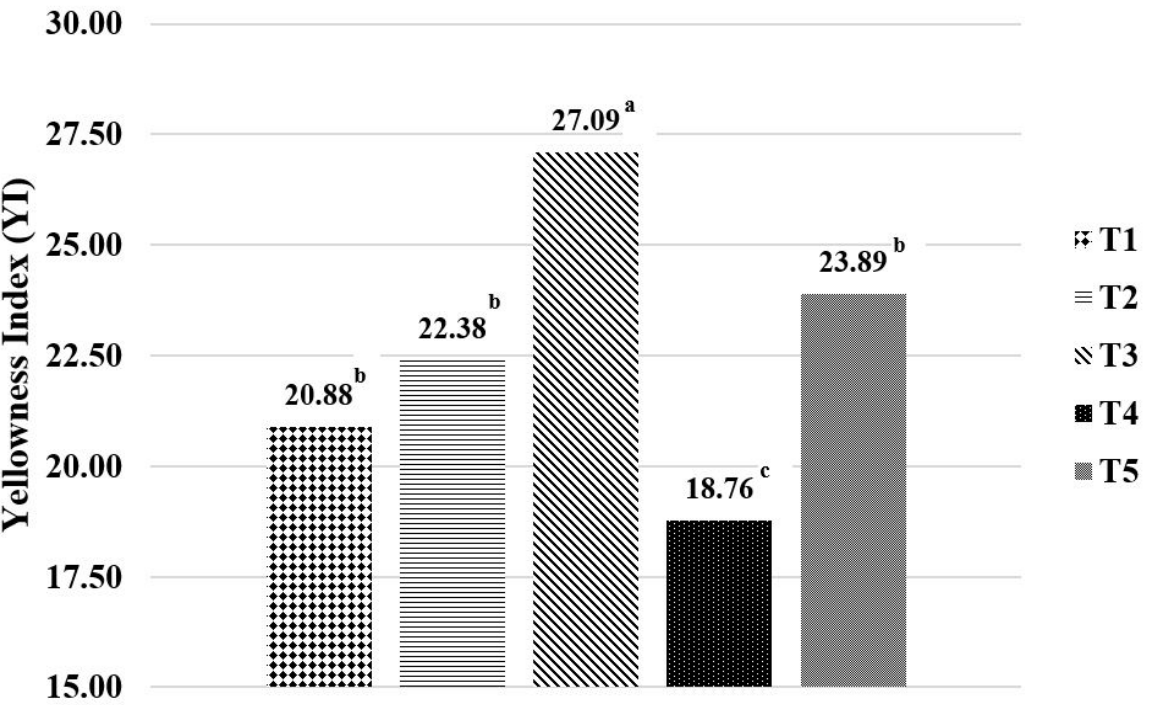

Figure 3. Yellowness index of yoghurt samples using CBG. T1: Full fat yoghurt (18\%), T2: Reduced fat yoghurt (12\%), T3: Low fat yoghurt (6\%), T4: Reduced fat yoghurt with CBG (12\%), T5: Low fat yoghurt with CBG (6\%).

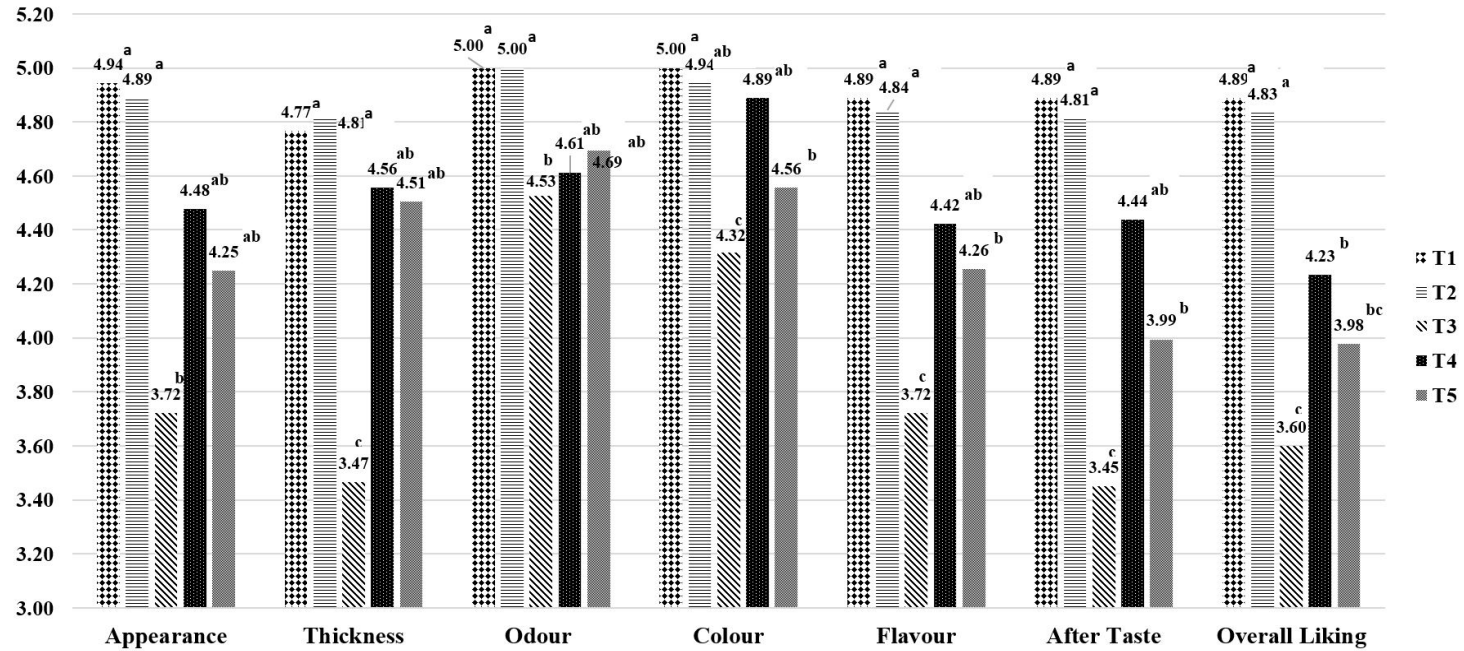

Figure 4. Sensory properties of yoghurt samples using CBG. T1: Full fat yoghurt (18\%), T2: Reduced fat yoghurt (12\%), T3: Low fat yoghurt (6\%), T4: Reduced fat yoghurt with CBG (12\%), T5: Low fat yoghurt with CBG (6\%). 


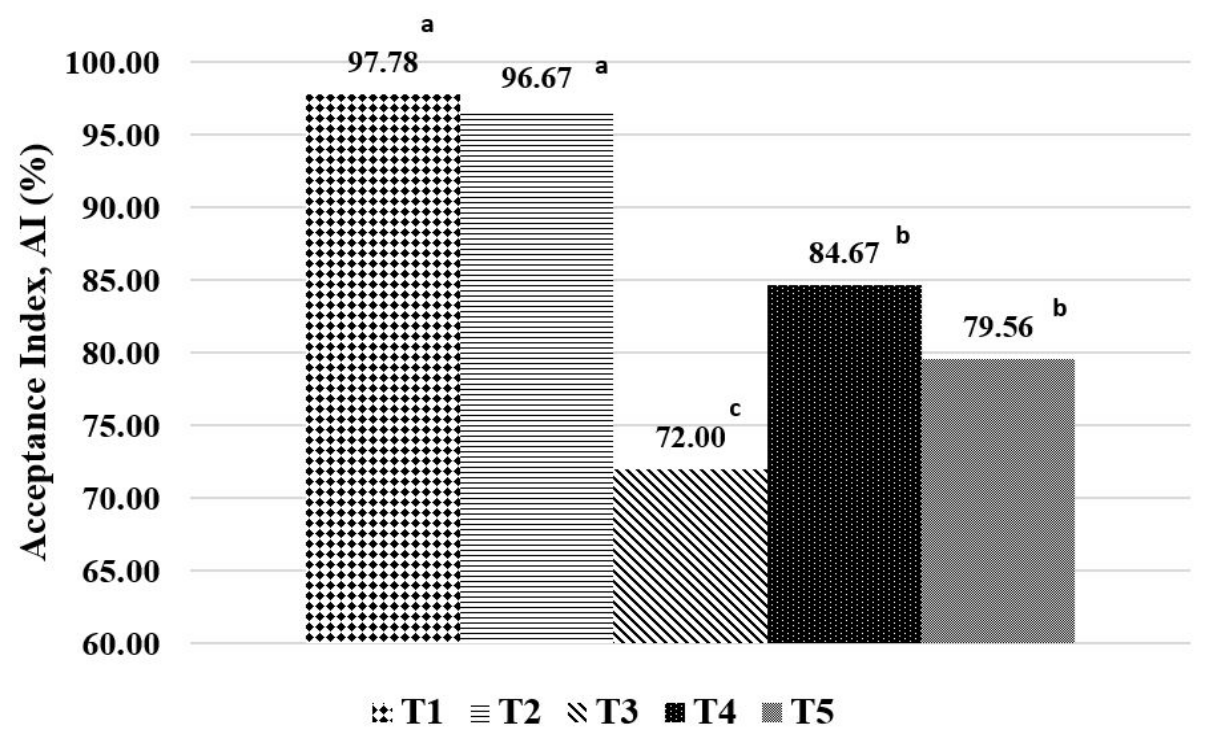

Figure 5. Acceptance index (AI) of yoghurt samples using CBG. T1: Full fat yoghurt (18\%), T2: Reduced fat yoghurt (12\%), T3: Low fat yoghurt (6\%), T4: Reduced fat yoghurt with CBG (12\%), T5: Low fat yoghurt with CBG (6\%).

Gums are polysaccharides of natural origin that increase textural quality (viscosity, syneresis), flavour intensity and flavour release of food products (Khaledabad et al., 2019). These polysaccharides could be utilise of sensory properties of dairy products by changing the rheological characteristics (Fagan et al., 2006; Peng \& Yao, 2017). The addition of CBG to reduced fat $(12 \%, \mathrm{~T} 4)$ and low fat $(6 \%, \mathrm{~T} 5)$ yoghurts improved the sensory properties enhancing gelation and curd structure with desired flavour (Figure 4).

The low fat yoghurt produced without the CBG (T3), had the lowest values, however, yoghurts with CBG $(\mathrm{T} 4, \mathrm{~T} 5)$ were more favourable in terms of sensory properties (Figure 4). The AI of yoghurt samples were shown in Figure 5. In relation to the sensory properties, the AI value was found to be higher in the reduced and low fat yoghurt (6 and $12 \%$ fat) samples with CBG than in the samples without CBG $(p<0.01)$.

\section{Conclusion}

Considering the rapidly increasing world population, dairy products have an important place in the nutrition of individuals. Milk fat is an essential ingredient that causes sensory perception of biting and mouthfeel. Low fat dairy products are usually characterized as having poor functional properties. Various stabilizers could be used to improve the textural and sensory properties of yoghurt. This study was carried out to reveal the effects of carob bean gum on the technological properties of yoghurts. Using of carbohydrate based fat replacer CBG in yoghurt formulation could solve the problems associated with enhancing technological properties. In conclusion, addition of CBG to yoghurt milk improved the textural and sensorial properties of reduced and low fat yoghurts. Moreover, dietary fats are not just energy-rich components but also essential lipid components. Therefore, it is important to remember that diets with reduced fat can not be considered as a permanent treatment for obesity and other diseases.

\section{References}

Alwazeer, D., Bulut, M., \& Tunçtürk, Y. (2020). Fortification of milk with plant extracts modifies the acidification and reducing capacities of yoghurt bacteria. International Journal of Dairy Technology, 73(1), 117-125. http://dx.doi.org/10.1111/1471-0307.12643.

Arslaner, A. (2020). The effects of adding garlic (Allium sativum L.) on the volatile composition and quality. Food Science and Technology, 40(Suppl. 2), 582-591. http://dx.doi.org/10.1590/fst.31019.

Aryana, K. J., \& Haque, Z. U. (2001). Effect of commercial fat replacers on the microstructure of low-fat cheddar cheese. International Journal of Food Science \& Technology, 36(2), 169-177. http://dx.doi. org/10.1046/j.1365-2621.2001.00446.x.

Aydinol, P., \& Ozcan, T. (2018). Production of reduced-fat Labneh cheese with inulin and $\beta$-glucan fibre-based fat replacer. International Journal of Dairy Technology, 71(2), 362-371. http://dx.doi.org/10.1111/14710307.12456.

Barak, S., \& Mudgil, D. (2014). Locust bean gum: processing, properties and food applications: a review. International Journal of Biological Macromolecules, 66, 74-80. http://dx.doi.org/10.1016/j. ijbiomac.2014.02.017. PMid:24548746.

Barros, R. F., Torres, F. R., Silva, P. H. F., Stringheta, P. C., Pereira, J. P. F., Paula, J. C. J., Cutrim, C. S., \& Cortez, M. A. S. (2020). Lutein as a functional ingredient in sheep milk yogurt: development, characterization and extraction recovery. Food Science and Technology, 40(Suppl. 2), 683-690. http://dx.doi.org/10.1590/fst.36019.

Batal, H. E., Hasib, A., Ouatmane, A., Boulli, A., Dehbi, F., \& Jaouad, A. (2013). Yield and composition of carob bean gum produced from different Moroccan populations of carob (Ceratonia siliqua L.). Journal of Materials and Environmental Science, 4, 309-314.

Bengoechea, C., Romero, A., Villanueva, A., Moreno, G., Alaiz, M., Millán, F., Guerrero, A., \& Puppo, M. C. (2008). Composition and structure of carob (Ceratonia siliqua L.) germ proteins. Food Chemistry, 107(2), 675-683. http://dx.doi.org/10.1016/j.foodchem.2007.08.069.

Bouzouita, N., Khaldi, A., Zgoulli, S., Chebil, L., Chekki, R., Chaabouni, M., \& Thonart, P. (2007). The analysis of crude and purified locust bean gum: a comparison of samples from different carob tree 
populations in Tunisia. Food Chemistry, 101(4), 1508-1515. http:// dx.doi.org/10.1016/j.foodchem.2006.03.056.

Brennan, C. S., \& Tudorica, C. M. (2008). Carbohydrate-based fat replacers in the modification of the rheological, textural and sensory quality of yoghurt: Comparative study of the utilisation of barley beta-glucan, guar gum and inulin. International Journal of Food Science \& Technology, 43(5), 824-833. http://dx.doi.org/10.1111/ j.1365-2621.2007.01522.x.

Brighenti, M., Govindasamy-Lucey, S., Lim, K., Nelson, K., \& Lucey, J. A. (2008). Characterization of the rheological, textural, and sensory properties of samples of commercial US cream cheese with different fat contents. Journal of Dairy Science, 91(12), 4501-4517. http:// dx.doi.org/10.3168/jds.2008-1322. PMid:19038925.

Calorie Control Council - CCC (2002). What the labels mean? Retrieved from http://www.caloriecontrol.org/foodlabels.html

Canbulat, Z., \& Ozcan, T. (2015). Effects of short-chain and long-chain inulin on the quality of probiotic yogurt containing Lactobacillus rhamnosus. Journal of Food Processing and Preservation, 39(6), 1251-1260. http://dx.doi.org/10.1111/jfpp.12343.

Ceylan, O., \& Ozcan, T. (2020). Effect of the cream cooling temperature and acidification method on the crystallization and textural properties of butter. Lebensmittel-Wissenschaft + Technologie, 132, 109806. http://dx.doi.org/10.1016/j.lwt.2020.109806.

Dai, S., Jiang, F., Corke, H., \& Shah, N. P. (2018). Physicochemical and textural properties of Mozzarella cheese made with konjac glucomannan as a fat replacer. Food Research International, 107, 691-699. http:// dx.doi.org/10.1016/j.foodres.2018.02.069. PMid:29580536.

Dakia, P. A., Blecker, C., Robert, C., Wathelet, B., \& Paquot, M. (2008). Composition and physicochemical properties of locust bean gum extracted from whole seeds by acid or water dehulling pre-treatment. Food Hydrocolloids, 22(5), 807-818. http://dx.doi.org/10.1016/j. foodhyd.2007.03.007.

DeHond, I., Miguel, E., \& Del Castillo, M. D. (2018). Food by products as sustainable ingredients for innovative and healthy dairy foods. Nutrients, 10(10), 1358-1384. http://dx.doi.org/10.3390/nu10101358.

Delaš, I. (2011). Benefits and hazards of fat-free diets. Trends in Food Science \& Technology, 22(10), 576-582. http://dx.doi.org/10.1016/j. tifs.2011.08.008.

Dionísio, M., \& Grenha, A. (2012). Locust bean gum: exploring its potential for biopharmaceutical applications. Journal of Pharmacy \& Bioallied Sciences, 4(3), 175-185. http://dx.doi.org/10.4103/09757406.99013. PMid:22923958.

Duboc, P., \& Mollet, B. (2001). Applications of exopolysaccharides in the dairy industry. International Dairy Journal, 11(9), 759-768. http://dx.doi.org/10.1016/S0958-6946(01)00119-4.

Fagan, C. C., O’Donnell, C. P., Cullen, P. J., \& Brennan, C. S. (2006). The effect of dietary fibre inclusion on milk coagulation kinetics. Journal of Food Engineering, 77(2), 261-268. http://dx.doi.org/10.1016/j. jfoodeng.2005.06.030.

Folkenberg, D. M., \& Martens, M. (2003). Sensory properties of low fat yoghurts. Part A: effect of fat content, fermentation culture and addition of non-fat dry milk on the sensory properties of plain yoghurts. Milchwissenschaft. Milk Science International, 58, 48-51.

Gunasekaran, S., \& Ak, M. M. (2003). Cheese rheology and texture. Boca Raton: CRC Press.

Janhoj, T., Frost, M. B., Prinz, J., \& Ipsen, R. (2009). Sensory and instrumental characterization of low-fat and non-fat cream cheese. International Journal of Food Properties, 12(1), 211-227. http://dx.doi. org/10.1080/10942910802252007.
Jung, H., \& Sato, T. (2013). Comparison between the color properties of whiteness index and yellowness index on the CIELAB. Textile Coloration and Finishing, 25(4), 241-246. http://dx.doi.org/10.5764/ TCF.2013.25.4.241

Kaaki, D., Kebbe Baghdadi, O., Najm, N. E., \& Olabi, A. (2012). Preference mapping of commercial Labneh (strained yogurt) products in the Lebanese market. Journal of Dairy Science, 95(2), 521-532. http:// dx.doi.org/10.3168/jds.2011-4409. PMid:22281316.

Khaledabad, M. A., Ghasempour, Z., Kia, E. M., Bari, M. R., \& Zarrin, R. (2019). Probiotic yoghurt functionalised with microalgae and Zedo gum: chemical, microbiological, rheological and sensory characteristics. International Journal of Dairy Technology, 73(1), 65-75. http://dx.doi.org/10.1111/1471-0307.12625.

Lashkari, H., Khosrowshahi Asl, A., Madadlou, A., \& Alizadeh, M. (2014). Chemical composition and rheology of low-fat Iranian white cheese incorporated with guar gum and gum arabic as fat replacers. International Journal of Food Science \& Technology, 51(10), 25842591. http://dx.doi.org/10.1007/s13197-012-0768-y. PMid:25328199.

Leroy, F., \& De Vuyst, L. (2004). Lactic acid bacteria as functional starter cultures for the food fermentation industry. Trends in Food Science \& Technology, 15(2), 67-78. http://dx.doi.org/10.1016/j. tifs.2003.09.004.

Lim, J., Inglett, G. E., \& Lee, S. (2010). Response to consumer demand for reduced-fat foods; multi-functional fat replacers. Nihon Shokuhin Kogakkaishi, 11(4), 147-152. http://dx.doi.org/10.11301/jsfe.11.147.

Lobato-Calleros, C., Ramirez-Santiago, C., Osorio-Santiago, V. J., Vernon-Carter, E. J., \& Hornelas-Uribe, Y. (2002). Microstructure and texture of Manchego cheese-light products made with canola oil, lipophilic, and hydrophilic emulsifiers. Journal of Texture Studies, 33(3), 165-182. http://dx.doi.org/10.1111/j.1745-4603.2002.tb01343.x.

Metzger, L. E., \& Kapoor, R. (2007). Novel approach for producing with reduced-fat and reduced sodium content. Journal of Dairy Science, 86, 198.

Moreira, L. R. S., \& Ferreira, E. X. Fo. (2008). An overview of mannan structure and mannan degrading enzyme systems. Applied Microbiology and Biotechnology, 79(2), 165-178. http://dx.doi.org/10.1007/s00253008-1423-4. PMid:18385995.

Ozcan, T. (2013). Determination of yogurt quality by using rheological and textural parameters. Food Science \& Nutrition, 53, 118-122. http://dx.doi.org/10.7763/IPCBEE.2013.V53.23.

Pathare, P. B., Opara, U. L., \& Al-Said, F. A. (2013). Colour measurement and analysis in fresh and processed foods: A review. Food and Bioprocess Technology, 6(1), 36-60. http://dx.doi.org/10.1007/ s11947-012-0867-9.

Peng, X., \& Yao, Y. (2017). Carbohydrates as fat replacers. Annual Review of Food Science and Technology, 8(1), 331-351. http://dx.doi. org/10.1146/annurev-food-030216-030034. PMid:28245156.

Pollard, M., Kelly, R., Wahl, C., Fischer, K. P., Windhab, E., Eder, B., \& Amado, R. (2007). Investigation of equilibrium solubility of a carob galactomannan. Food Hydrocolloids, 21(5-6), 683-692. http://dx.doi. org/10.1016/j.foodhyd.2006.08.010.

Ribeiro, A. S., Silva, M. N., Tagliapietra, B. L., Brum, B. S. Jr., Ugalde, M. L., \& Richards, N. S. P. S. (2019). Development of symbiotic yoghurt and biological evaluation (New Zealand White Rabbits) of its functional properties. Food Science and Technology, 39(Suppl. 2), 418-425. http://dx.doi.org/10.1590/fst.20618.

Rinaudo, M. (2008). Main properties and current applications of some polysaccharides as biomaterials. Polymer International, 57(3), $397-$ 430. http://dx.doi.org/10.1002/pi.2378. 
Rogers, N. R., McMahon, D. J., Daubert, C. R., Berry, T. K., \& Foegeding, E. A. (2010). Rheological properties and microstructure of Cheddar cheese made with different fat contents. Journal of Dairy Science, 93(10), 4565-4576. http://dx.doi.org/10.3168/jds.2010-3494. PMid:20854990.

Romeih, E. A., Michaelidou, A., Biliaderis, C. G., \& Zerfiridis, G. K. (2002). Low-fat white-brined cheese made from bovine milk and two commercial fat mimetics: chemical, physical and sensory attributes. International Dairy Journal, 12(6), 525-540. http://dx.doi. org/10.1016/S0958-6946(02)00043-2.

Sandrou, D. K., \& Arvanitoyannis, I. S. (2000). Low-fat/calorie foods: current state and perspectives. Critical Reviews in Food Science and Nutrition, 40(5), 427-447. http://dx.doi.org/10.1080/10408690091189211. PMid:11029012.

Sattar, M. U., Sameen, A., Huma, N., \& Shahid, M. (2015). Exploit fat mimetic potential of different hydrocolloids in low fat Mozzarella cheese. Journal of Food and Nutrition Research, 3, 518-525. http:// dx.doi.org/10.12691/jfnr-3-8-7.
Silva, P., Varela, M., \& Correia, R. (2010). Composition, sensory evaluation and melting properties of caprine ice cream produced with different fat sources. Revista do Instituto Adolfo Lutz, 69, 341-345.

Simeone, M., Alfani, A., \& Guido, S. (2004). Phase diagram, rheology and interfacial tension of aqueous mixtures of $\mathrm{Na}$-caseinate and Na-alginate. Food Hydrocolloids, 18(3), 463-470. http://dx.doi. org/10.1016/j.foodhyd.2003.08.004.

Totosaus, A., \& Guemes-Vera, N. (2008). Effect of $\kappa$ - and $\lambda$-carrageenans as fat-replacers in low-fat Oaxaca cheese. International Journal of Food Properties, 11(3), 656-668. http://dx.doi.org/10.1080/10942910701594111.

Yilmaz-Ersan, L., Ozcan, T., Akpinar-Bayizit, A., Usta, B., Kandil, M., \& Eroglu, E. (2018). The effect of gums on the growth of Bifidobacterium longum. Fresenius Environmental Bulletin, 27, 4270-4276.

Zhu, B. J., Zayed, M. Z., Zhu, H. X., Zhao, J., \& Li, S. P. (2019). Functional polysaccharides of carob fruit: a review. Chinese Medical Journal, 40, 14-23. http://dx.doi.org/10.1186/s13020-019-0261-x. PMid:31583011. 